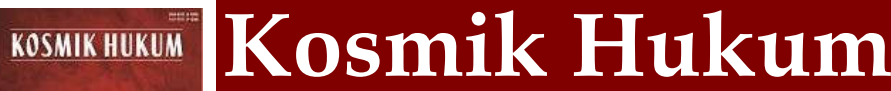

Fakultas Hukum

Universitas Muhammadiyah Purwokerto

Vol. 21 No. 1 (2021)

This work is licensed under a Attribution-NonCommercial 4.0 International License (CC BY-NC 4.0)

\section{Akibat Hukum Pandemi Covid-19 sebagai Bencana Non Alam Medis dalam Menetapkan Force Majeure di Indonesia}

\author{
Peni Jati Setyowati ${ }^{\mathbb{X}}$ \\ Fakultas Hukum Universitas Wijaya Kusuma Surabaya, Indonesia \\ E-mail Korespondensi: penijati.fh@uwks.ac.id
}

\begin{abstract}
A contract forms a private entity between the parties involved, herein each party has the legal rights to demand the implementation or fulfillment of all elements contained in the contract. However, such legal relationship through the contract does not always fulfil the expectation and purpose. This might occur because the involved parties have committed breach of contract / default. Such condition can occur and be done by both parties because of coercion, error, fraud, or force majeure. In a more specific context, there are several causes of force majeure. The current condition of global pandemic of covid-19, including in Indonesia, has affected the implementation of an ongoing contract between involved parties becomes disrupted, even can result in null or not fulfilled the goals in the contract. Therefore, it is important for contract parties to understand more deeply about force majeure in responding to the latest condition. This normative legal research is intended to find out how the impact of the covid-19 pandemic on the force majeure clause of the contracts in Indonesia.
\end{abstract}

Keywords: national disaster, covid-19, Indonesia, force majeure

\begin{abstract}
Abstrak
Sebuah kontrak membentuk suatu entitas privat antara para pihak yang terlibat di dalamnya, dimana masing-masing pihak memiliki hak secara yuridis untuk menuntut pelaksanaan atau dipenuhinya segala unsur yang ada dalam kontrak tersebut. Namun, hubungan hukum yang lahir melalui kontrak/kontrak tersebut tidak selalu terpenuhi maksud atau tujuannya (prestasi). Hal tersebut dapat terjadi karena pihak yang terikat dalam kontrak tersebut melakukan cidera janji atau breach of contract (wanprestasi). Wanprestasi ini dapat terjadi dan dilakukan baik itu oleh kedua belah pihak, karena adanya paksaan, kekeliruan, kecurangan, maupun keadaan kahar/memaksa atau yang dikenal sebagai force majeure. Spesifiknya, ada beberapa penyebab terjadinya force majeure. Kondisi terkini, terjadinya Pandemi Covid-19 telah menyebar ke seluruh dunia, khususnya Indonesia, maka pelaksanaan terhadap suatu kontrak yang sedang berlangsung diantara para pihak yang terikat menjadi terganggu, bahkan dapat berakibat batal atau tidak terpenuhinya prestasi dalam kontrak tersebut. Oleh karenanya, penting bagi para pihak kontrak untuk memahami lebih mendalam mengenai force majeure dalam menyikapi kondisi terkini. Metode penelitian ini menggunakan penelitian hukum normatif. Tujuan dari penelitian ini adalah untuk mengetahui bagaimana dampak pandemic covid-19 terhadap klausul force majeure dalam kontrak di Indonesia.
\end{abstract}

Kata Kunci: Bencana Nasional, Covid 19, Indonesia, Force majeure.

Copyright@2021KosmikHukum. All rights reserved.

\section{Pendahuluan}

Sejak kasus pertama virus ini ditemukan pada November 2019 silam di Wuhan China, jumlah kasus terus mengalami eskalasi yang signifikan. World Health Organisation (WHO) merilis data, sampai dengan tanggal 13 April 2020 pukul 07.00 GMT+7, tercatat 1.776.867 kasus Covid19, termasuk diantaranya 111.828 angka kematian. Pada tanggal 2 Maret 2020, Indonesia 
Kosmik Hukum Vol. 21 No. 1 (2021): 1-9

E-ISSN: 2655-9242 | P-ISSN: 1411-9781

DOI: 10.30595/kosmikhukum.v21i1.9407

dihadapkan dengan kasus pertama orang dengan positif COVID-19. ${ }^{1}$ COVID-19 menyebar begitu cepat karena penularannya melalui kontak langsung dari manusia ke manusia. Noah C. Peeri ${ }^{2}$ mengemukakan bahwa "the virus spread internationally within 1 month of the first identification, and can be transmitted via close human-to human contact." World Health Organization (WHO) sejak tanggal 11 Maret 2020 menyatakan bahwa COVID-19 sebagai Global Pandemic.

Imbauan kepada masyarakat untuk melakukan physical distancing, kampanye "\#dirumahaja" serta langkah-langkah pembatasan aktivitas melalui sejumlah aturan yang diambil Pemerintah sejatinya dimaksudkan untuk menekan penyebaran Covid-19. Di sisi lain, physical distancing dan pembatasan aktivitas tersebut secara tidak langsung membuat aktivitasaktivitas masyarakat di tempat umum, tempat perbelanjaan, destinasi wisata, dan perkantoran berkurang secara signifikan. Berkurangnya aktivitas masyarakat membuat ujian yang cukup berat bagi kegiatan ekonomi.

Kondisi ini mengakibatkan pengusaha, kontraktor, pekerja, dan seluruh lini masyarakat mengalami dampak akibat datangnya virus Covid-19 di Indonesia. Sektor yang paling berdampak akibat kondisi ini adalah sektor bisnis, ekonomi, sosial dan ketenagakerjaan. Oleh karenanya, kemudian Pemerintah Indonesia mengeluarkan pengumuman bahwa datangnya virus covid 19 merupakan bencana nasional dan merupakan kondisi pandemi wabah. Pengumuman Pemerintah yang disampaikan oleh Presiden RI Joko Widodo, Pemerintah menyatakan kondisi tersebut melalui Keputusan Presiden Nomor 12 Tahun 2020 tentang Penetapan Bencana Non Alam Penyebaran Corona Virus Disease 2019 (COVID-19) sebagai Bencana Nasional.

\section{Rumusan Masalah}

Berdasarkan uraian tersebut diatas, rumusan masalah yang akan dikaji dalam penelitian ini adalah:

1. Karakter klausul Force majeure terhadap Bencana Non Alam Medis Penyebaran Covid 19.

2. Dampak Penetapan Bencana Non Alam Medis Penyebaran Covid 19 sebagai Force majeure di Indonesia.

\section{Metode Penelitian}

Penelitian hukum merupakan proses untuk menemukan aturan hukum, prinsip-prinsip hukum maupun doktrin-doktrin hukum guna menjawab isu hukum yang dihadapi. ${ }^{3}$ Suatu argumentasi hukum, teori atau konsep hukum baru yang dihasilkan dalam penelitian hukum ini merupakan preskripsi untuk menyelesaikan permasalahan-permasalahan yang dihadapi. Dalam penelitian ini menggunakan penelitian hukum normatif yang bertujuan untuk mengkaji penerapan kaidah-kaidah atau norma dalam hukum positif yang objek kajiannya adalah dokumen peraturan perundang-undangan dan bahan pustaka. Penelitian ini menggunakan pendekatan perundang-undangan (Statute Approach) dengan menelaah peraturan perundangundangan terkait dengan rumusan masalah, yaitu dalam hal ini mengkaji KUHPerdata serta Keputusan Presiden Nomor 12 Tahun 2020.

Gugus Tugas Percepatan Penanganan COVID-19.“Infografis COVID-19 (17 Mei 2020)”. Dikutip dari laman: https://covid19.go.id/p/berita/infografis-covid-19-17-mei-2020, (2020). diakses 1 Mei 2020.

2 Peeri, N. C, et. al.“The SARS, MERS and novel coronavirus (COVID-19)epidemics, the newest and biggest global health threats: what lessons have we learned?". International Journal of Epidemiology, 2020, .hlm. 1-10.

Peter Mahmud Marzuki, "Penelitian Hukum", Kencana Prenada Media Group, Jakarta, 2011, (selanjutnya disebut Peter Mahmud Marzuki I), hlm. 35. 


\section{Hasil dan Pembahasan}

\section{Karakter klausul Force majeure terhadap Bencana Non Alam Medis Penyebaran Covid-19}

Pemerintah Indonesia telah menetapkan COVID-19 sebagai jenis penyakit yang menimbulkan kedaruratan kesehatan masyarakat. Berdasarkan Keputusan Presiden Nomor 12 Tahun 2020 tentang Penetapan Bencana Non Alam Penyebaran Covid 19 sebagai Bencana Nasional. Oleh karena itu, dalam rangka menghambat penyebaran COVID-19, Pemerintah mengambil langkah dengan menetapkan pandemi Covid-19 sebagai bencana nasional dan mengimbau masyarakat untuk melakukan physical distancing serta bekerja/belajar dari rumah.

Imbauan Pemerintah ini diikuti dengan dikeluarkannya sejumlah payung hukum diantaranya, Peraturan Pemerintah Nomor 21 Tahun 2020 tentang Pembatasan Sosial Berskala Besar Dalam Rangka Percepatan Penanganan Corona Virus Disease 2019 (COVID-19), Keputusan Presiden Nomor 11 Tahun 2020 tentang Penetapan Kedaruratan Kesehatan Masyarakat Corona Virus Disease 2019 (COVID-19), Peraturan Menteri Kesehatan Republik Indonesia Nomor 9 Tahun 2020 tentang Pedoman Pembatasan Sosial Berskala Besar Dalam Rangka Percepatan Penanganan Corona Virus Disease 2019 (COVID-19). Terakhir, melalui Keputusan Presiden Nomor 12 Tahun 2020 tentang Penetapan Bencana Non Alam Penyebaran Corona Virus Disease 2019 (COVID-19) sebagai Bencana Nasional.

Dampak dari diterbitkannya Keputusan Presiden tersebut berbagai sektor mengalami hambatan untuk melaksanakan kewajiban dan mendapatkan haknya. Mengingat, anjuran yang dikeluarkan Pemerintah adalah untuk tetap di rumah saja pada beberapa sektor dan dengan adanya penerapan Pembatasan Sosial Berskala Besar pada beberapa wilayah di Indonesia. Kondisi ini tentu merugikan beberapa sector dan berimbas pada pelaksanaan kontrak. Salah satu klausul yang dapat dirujuk untuk mengatasi permasalahan dalam hal pelaksanaan kontrak adalah klausul Force majeure.

Menurut Black's Law Dictionary 4 , force majeure adalah "an event or effect that can be neither anticipated nor controlled". Dalam hukum perdata materiil Indonesia, istilah force majeure memang tidak diatur secara tegas. Pasal yang sering digunakan sebagai acuan dalam pembahasan force majeure, yakni Pasal 1244 dan Pasal 1245 KUH Perdata yang berbunyi sebagai berikut: Pasal 1244 KUH Perdata: Debitur harus dihukum untuk mengganti biaya, kerugian dan bunga bila ia tak dapat membuktikan bahwa tidak dilaksanakannya perikatan itu atau tidak tepatnya waktu dalam melaksanakan perikatan itu disebabkan oleh sesuatu hal yang tak terduga, yang tak dapat dipertanggungkan kepadanya walaupun tidak ada itikad buruk kepadanya. Pasal 1245 KUH Perdata: Tidak ada penggantian biaya, kerugian dan bunga bila karena keadaan memaksa atau karena hal yang terjadi secara kebetulan, debitur terhalang untuk memberikan atau berbuat sesuatu yang diwajibkan, atau melakukan suatu perbuatan yang terlarang baginya.

Berdasarkan ketentuan tersebut, maka unsur utama yang dapat menimbulkan keadaan force majeure adalah:

1) Adanya kejadian yang tidak terduga;

2) Adanya halangan yang menyebabkan suatu prestasi tidak mungkin dilaksanakan;

3) Ketidakmampuan tersebut tidak disebabkan oleh kesalahan debitur dan

4) Ketidakmampuan tersebut tidak dapat dibebankan risiko kepada debitur.

Dari uraian penjelasan mengenai ketentuan Pasal 1245 KUHPerdata dan Black's Law Dictionary tersebut, terdapat persamaan, yaitu pihak tidak dapat diminta ganti rugi dalam hal terdapat keadaan yang tidak dapat diperkirakan sebelumnya atau diluar kendali yang wajar karena adanya faktor eksternal. Dalam konteks pandemi COVID-19, apakah keadaan memaksa (force majeure) dapat terpenuhi secara hukum? Atau, apakah klaim force majeure tetap harus merujuk pada kontrak yang disepakati para pihak? Hal ini tentu saja menimbulkan keresahan bagi para pengusaha dan kontraktor maupun para pelaku bisnis.

\footnotetext{
${ }^{4}$ Garner, Bryan A., ed, Black's Law Dictionary, Tenth Edition, West Publishing Company, USA, 2014.
} 
Kosmik Hukum Vol. 21 No. 1 (2021): 1-9

E-ISSN: 2655-9242 | P-ISSN: 1411-9781

DOI: $10.30595 /$ kosmikhukum.v21i1.9407

Berdasarkan ketentuan Pasal 1245 KUHPerdata yang tercantum di dalam Buku Ketiga tentang Perikatan pada Bab I tentang Perikatan Pada umumnya, dijelaskan bahwa ketentuan Pasal 1245 KUH Perdata sejatinya berlaku bagi para pihak dalam suatu perikatan dengan syarat, pertama, para pihak menundukkan diri bahwa hukum perdata yang berlaku di Indonesia sebagai governing law; dan kedua, para pihak tidak mengatur secara khusus mengenai klausula force majeure dalam perikatan.

Munculnya kasus pertama Covid-19 di Indonesia, membuat Pemerintah untuk segera membentuk Tugas Gugus Pencegahan Penyebaran Virus Covid-19. Segala upaya telah dilakukan Pemerintah untuk menekan angka penyebaran virus covid-19 ini. Salah satu upaya yang dilakukan Pemerintah adalah mengeluarkan Keputusan Presiden Nomor 12 Tahun 2020 tentang Penetapan Bencana Nonalam Penyebaran Corona Virus Disease 2019 (Covid-19) sebagai Bencana Nasional. Hadirnya Keputusan Presiden ini menimbulkan keresahan bagi para pelaku bisnis dan kontraktor. Hal ini berkaitan dengan klausul Force majeure dalam kontrak pada masa pandemik virus covid-19 ini.

Berdasarkan hal tersebut, maka apabila kondisi saat ini ditetapkan sebagai keadaan Kahar atau force majeure, hal ini kemudian akan berdampak pada kesehatan dan resiko dalam perekonomian Indonesia. Contohnya dalam sektor perbankan, akan mengalami kesulitan modal sehingga berdampak pada kesehatan bank tersebut. Hal ini disebabkan karena konsekuensinya akan banyak hutang yang secara hukum dianggap lunas jika force majeure ditetapkan. Contoh lain dalam sector infrastruktur. Kondisi saat ini, keadaan memaksa atau force majeure dikenal dalam hukum perdata, merupakan kondisi yang terjadi setelah dibuat kontrak atau kontrak yang menghalangi salah satu pihak untuk memenuhi kewajibannya atau prestasinya. Dalam keadaan force majeure, pihak yang tidak menjalankan kewajiban tidak bisa dinyatakan sebagai wanprestasi. Kondisi bencana covid 19 ini bukan merupakan keadaan kahar atau force majeure. Semua kontrak atau kontrak bisnis harus tetap berjalan semua. Sektor Perbankan tidak perlu khawatir, debitur lakukan restrukturisasi hutang saja, karena dalam Pasal 1320 KUH Perdata tetap mengikat para pihak dalam kontrak atau kontrak.

Kontrak yang telah berjalan tidak dapat dibatalkan karena Virus Corona, Corona bukan keadaan memaksa. Beberapa pekerja masih dapat bekerja. Selain itu, pandemi Virus Corona atau Covid-19 bukan merupakan kondisi yang tidak dapat diprediksi oleh Pemerintah Pusat, sehingga menjadikan keadaan seolah memaksa. Pemerintah Pusat seyogyanya sudah dapat memprediksi wabah Virus Corona atau Covid-19 bisa masuk ke Indonesia, setelah ada 25 negara yang sudah terkena pandemi virus corona tersebut pada awal Februari 2020.

Berdasarkan beberapa fakta hukum yang ada, bahwa Virus Corona ini tidak bisa dijadikan keadaan force majeure. Hal ini disebabkan karena, unsur-unsur bencana alam covid 19 tidak dapat ditetapkan sebagai kondisi Force majeure. Salah satu unsur terjadinya bencana alam Covid-19 ini adalah keadaan tak terduga. Hal ini disebabkan karena virus corona datang ke Indonesia secara terduga. Kondisi Pandemi Covid 19 ini baru dapat dikatakan tidak terduga adalah apabila Virus Corona berasal dari Indonesia, maka hal itu dapat dinyatakan sebagai kondisi tidak terduganya.

Penerapan Bencana Pandemi Covid 19 sebagai bentuk Force Majeure harus dilihat kembali pada klausul kontrak dalam kasus per kasus dan tidak dapat diterapkan secara keseluruhan. Penerapan ini merujuk pada Asas Kesepakatan yang telah tertuang dalam masingmasing kontrak. Para pihak harus melihat kontrak yang telah ditandatangani, berkaitan dengan klausul Force majeure, apakah sudah dengan jelas mencantumkan bahwa Pandemi merupakan salah satu dari Force majeure atau tidak. Apabila hal ini tidak dicantumkan dengan jelas dalam kontrak, maka Keputusan Presiden Nomor 12 Tahun 2020 tentang Penetapan Bencana Nasional Pandemi Covid 19 tidak dapat dirujuk sebagai penetapan Force majeure bagi para pihak dan tidak dapat dijadikan acuan untuk pengajuan klaim Force majeure bagi para pihak. pada umumnya, klausul Force Majeure hanya mencantumkan definisi sebagai berikut: "Yang dimaksud dengan force majeure adalah kejadian-kejadian seperti kebakaran, gempa bumi, banjir, huru-hara yang secara langsung mengakibatkan terjadinya keterlambatan dan/atau tidak 
dapat dilaksanakannya kewajiban yang tercantum dalam Perjanjian". Dalam hal ini berarti para pihak, harus melihat kembali apakah isi dari kontrak tersebut, khususnya klausul Force Majeure sudah menyebutkan bahwa pandemic adalah sebagai bagian dari kondisi Force Majeure.

\section{Dampak Penetapan Bencana Non Alam Medis Penyebaran Covid-19 sebagai Force majeure dalam Hukum Kontrak Indonesia}

Diterbitkannya Keputusan Presiden Nomor 12 Tahun 2020 tentang Penetapan Bencana Non alam Penyebaran Corona Virus Disease 2019 (Covid-19) sebagai Bencana Nasional tentu menimbulkan pertanyaan bagi para pelaku bisnis apakah hal ini dapat dijadikan dasar berlakunya keadaan memaksa (force majeure) terhadap kontrak-kontrak bisnis yang telah disepakati sebelum terbitnya Keppres tersebut. Pertanyaan ini menjadi wajar mengingat pada umumnya dalam suatu kontrak terdapat klausula atau pengaturan kedaan memaksa di dalamnya. Klausula tersebut memasukkan bencana alam seperti banjir, gempa bumi dan tanah longsor maupun bencana non alam seperti epidemik sebagai kedaan memaksa yang dapat membebaskan debitur atau pihak yang memiliki kewajiban dalam kontrak dari kewajiban membayar ganti rugi atas tidak terlaksananya kontrak.

Berbicara mengenai klausul force majeure, yang harus dipahami adalah tentang kontrak yang baik. Kontrak yang baik adalah kontrak yang dapat disepakati dan dijalankan oleh para pihak dengan pemenuhan persyaratan sebagaimana tercantum dalam Pasal 1320 Burgerlijk Wetboek (BW). Dalam Pasal 1320 BW dinyatakan bahwa kontrak sepenuhnya telah memenuhi unsur subyektif dan unsur obyektif, maka kontrak tersebut tidak terdapat indikasi cacat hukum. Bilamana adanya unsur yang tidak terpenuhi atau cacat hukum, maka akan menimbulkan problematika dalam pemenuhan prestasinya. Kontrak yang berlaku penuh sesuai dengan kesepakatan para pihak, dilandasi dengan itikad baik, dan tidak ada cacat hukum di dalamnya, maka kontrak dapat dinyatakan memenuhi kepastian hukum bagi para pihak.

Menurut Beatson mengungkapkan dua fungsi penting dari kontrak yaitu untuk menjamin terciptanya harapan terhadap janji yang telah dipertukarkan dan fungsi konstitutif untuk memberikan fasilitas terhadap transaksi yang direncanakan serta memberikan aturan bagi kelanjutannya ke depan. Dalam hubungannya dengan fungsi kontrak bagi perencanaan transaksi, Beatson menyebutkan empat hal yaitu:

1) Kontrak pada umumnya menetapkan nilai pertukaran;

2) Dalam kontrak terdapat kewajiban timbal balik dan standar pelaksanaan kewajiban;

3) Kontrak membutuhkan alokasi pengaturan tentang risiko ekonomi bagi para pihak;

4) Kontrak dapat mengatur kemungkinan kegagalandan konsekuensi hukumnya.

Sebuah kontrak membentuk suatu entitas privat di antara para pihak di mana masingmasing pihak memiliki hak secara yuridis untuk menuntut pelaksanaan serta kepatuhan terhadap pembatasan-pembatasan yang telah disepakati oleh pihak yang lain secara sukarela. ${ }^{5}$ Hubungan hukum yang lahir melalui kontrak tidak selalu terlaksana maksud dan tujuannya, keadaan tersebut dapat terjadi akibat wanprestasi baik itu dilakukan oleh kreditur maupun debitur, adanya paksaan, kekeliruan, perbuatan curang, maupun keadaan yang memaksa atau dikenal dengan force majeure atau dikenal dalam hukum Indonesia dengan overmacht. Konsekuensi yang muncul dari keadaan ini menyebabkan suatu kontrak (kontrak) dapat dibatalkan dan yang batal demi hukum. ${ }^{6}$

Berkaitan dengan klausul force majeure, pemahaman mengenai force majeure adalah kejadian luar biasa yang menyebabkan orang tidak mampu memenuhi prestasinya karena peristiwa yang di luar kemampuannya. Menurut pendapat Mahfud MD bahwa Keputusan Presiden Nomor 12 Tahun 2020 tidak bisa menjadi legitimasi force majeure untuk membatalkan kontrak hukum maupun kontrak. Pandemi COVID-19 tidak masuk dalam unsur-unsur force

Bayu Seto Hardjowahono (Ketua Tim), Naskah Akademik Rancangan Undang Undang Hukum Kontrak, Badan Pembinaan Hukum Nasional Kementerian Hukum Dan Ham RI, 2013, hlm. 3

${ }^{6}$ Elly Erawati, Herlien Budiono, Penjelasan Hukum Tentang Kebatalan Kontrak, Nasional Legal Reform Program-

Gramedia, Jakarta, 2010, hlm. 5' 
Kosmik Hukum Vol. 21 No. 1 (2021): 1-9

E-ISSN: 2655-9242 | P-ISSN: 1411-9781

DOI: $10.30595 /$ kosmikhukum.v21i1.9407

majeure. Pasalnya COVID-19 tidak datang secara tiba-tiba, seperti halnya gempa bumi, tsunami, atau bencana alam lainnya. Hal ini sejalan dengan pendapat dari para ahli, bahwa force majeure tidak dapat langsung membatalkan kontrak atau kontrak karena keadaan force majeure adalah keadaan yang dapat digunakan untuk bernegosiasi kembali bagi para pihak dalam kontrak yaitu mengenai hal-hal yang tidak mampu dipenuhi para pihak, Hal ini berlaku pula pada Hukum Ketenagakerjaan.

Dalam kaitannya dengan pelaksanaan kontrak konstruksi, klausul force majeure meliputi:

a. Keadaan memaksa yang bersifat mutlak (absolut), yakni bahwa para pihak tidak mungkin melaksanakan hak dan kewajibannya.

b. Keadaan memaksa yang bersifat tidak mutlak (relatif), yakni bahwa para pihak masih dimungkinkan untuk melaksanakan hak dan kewajibannya.

Selanjutnya dalam penjelasan Undang-Undang Nomor 2 Tahun 2017 tentang Jasa Konstruksi juga menyebutkan bahwa menggolongkan beberapa jenis keadaan kahar (force majeure) ke dalam peristiwa-peristiwa konkrit yang meliputi :

a. Bencana alam, yang termasuk bencana alam antara lain berupa gempa bumi, tsunami, gunung meletus, banjir, kekeringan angin topan, dan tanah longsor.

b. Bencana non alam, yang termasuk bencana non alam antara lain berupa gagal tehnologi, epidemik dan wabah penyakit.

c. Bencana sosial, yang termasuk bencana sosial antara lain konflik sosial antara kelompok atau antara komunitas masyarakat, dan teror

d. Pemogokan.

e. Kebakaran.

f. Gangguan industri lainnya

Dalam beberapa kontrak, dapat disimpulkan bahwa unsur-unsur force majeure antara lain:

a) terjadinya keadaan kejadian di luar kemauan, kemampuan atau kendali para pihak;

b) menimbulkan kerugian bagi para pihak atau salah satu pihak;

c) terjadinya peristiwa tersebut menyebabkan tertunda, terhambat, terhalang, atau tidak dilaksanakannya prestasipara pihak;

d) para pihak telah melakukan upaya sedemikian rupa untuk menghindari peristiwa tersebut

e) kejadian tersebut sangat mempengaruhi pelaksanaan perjanjian.

Batasan-batasan yang memenuhi keadaan force majeure pada kontrak konstruksi adalah sebagai berikut:

a. Tidak dapat diduga/diluar kemauan penyedia jasa.

b. Diluar kemampuan penyedia jasa untuk melaksanakan pekerjaan.

c. Terjadi kerugian bagi pengguna jasa.

Setelah terjadinya keadaan kahar, para pihak dapat melakukan kesepakatan, yang dituangkan dalam perubahan kontrak/addendum kontrak. Hal ini sesuai dengan yang tertuang dalam Pasal 55 Peraturan Presiden Nomor 16 Tahun 2018 tentang Pedoman Pengadaan Barang/Jasa yang telah diatur pula mengenai Keadaan Kahar (Force Majeure). Dalam Pasal ini dijelaskan bahwa dalam hal terjadinya keadaan kahar, maka pelaksanaan kontrak dapat dihentikan jika telah disepakati oleh para pihak. Terjadinya keadaan kahar, jangka waktu kontrak juga dapat diperpanjang meskipun telah melewati Tahun Anggaran. Perubahan jangka waktu ini juga wajib disertai adanya perubahan kontrak.

Dampak atau akibat hukum terjadinya force majeure dalam kaitannya pelaksanaan kontrak konstruksi adalah sebagai berikut :

1. Jika akibat force majeure tersebut penyedia jasa tidak mungkin untuk melaksanakan pekerjaannya (force majeur absolut), maka kontrak akan dihentikan. Berdasarkan doktrin para ahli hukum pada force majeure absolut menyebabkan pemenuhan prestasi tidak mungkin dilakukan lagi dan seketika itu kontrak putus. 
2. Jika akibat force majeure tersebut penyedia jasa masih dimungkinkan untuk melaksanakan pekerjaannya (force majeure relatif), maka kontrak dihentikan sementara (ditunda) atau kontrak dilanjutkan. Berdasarkan doktrin para ahli hukum pada force majeure relatif pemenuhan prestasi menjadi tertunda (dihentikan sementara) dan kontrak tidak putus.

3. Terkait dengan adanya kerugian akibat force majeure tersebut, yang menanggung kerugian adalah pengguna jasa. Karena tidak ada unsur kesalahan dari penyedia jasa yang mempunyai kewajiban melaksanakan pekerjaan. maka penyedia jasa tidak menanggung risiko dan tidak menanggung kerugian atas peristiwa itu. Berdasarkan doktrin para ahli hukum, karena tidak ada kesalahan dari penyedia jasa, maka penyedia jasa tidak menanggung kerugian.

Dalam hal ini, maka keadaan memaksa adalah suatu keadaan tidak terduga, tidak sengaja, dan tidak dapat dipertanggungjawabkan oleh debitur, dimana debitur tidak dapat melakukan prestasinya kepada kreditur dan dengan terpaksa peraturan hukum juga tidak diindahkan sebagai mana semestinya. Hal ini disebabkan adanya kejadian yang berada di luar kekuasaanya dan keadaan ini dapat dijadikan alasan untuk dibebaskan dari kewajiban membayar ganti kerugian ${ }^{7}$ Terdapat sejumlah unsur utama yang membuat sebuah kondisi dianggap sebagai force majeure, yaitu:

1) adanya kejadian tidak terduga;

2) halangan yang menyebabkan suatu prestasi tidak mungkin dilaksanakan;

3) Ketidakmampuan tersebut tidak disebabkan oleh kesalahan debitur; dan

4) ketidakmampuan tersebut tidak dapat dibebankan risiko kepada debitur.

Akibat luasnya kemungkinan keadaan atau situasi force majeure, para pihak yang terlibat dalam suatu kontrak hukum atau kontrak biasanya mencantumkan klausul dengan daftar peristiwa yang dapat menjadi force majeure dalam kontrak mereka. Hal ini guna mendapat kepastian hukum bagi para pihak.

Dampak penerapan klausul Force majeure bagi para pihak harus memuat hal berikut ini8:

1) Jika dalam kontrak disebutkan secara tegas menyatakan wabah penyakit (outbreak) atau penutupan akses (lockdown) sebagai peristiwa force majeure, maka wabah virus corona dan lockdown oleh pemerintah dapat dijadikan sebagai alasan force majeure. Jika tidak ada atau terdapat klausula yang menyatakan "kejadian-kejadian lain di luar kemampuan debitur" atau sejenisnya, maka berlaku poin selanjutnya;

2) Baik itu dinyatakan secara tegas atau tidak tegas dalam kontrak, yang harus diperhatikan adalah prestasinya, bukan semata peristiwanya serta peristiwa tersebut pun merupakan kejadian yang tidak dapat diduga sebelum dibuat kontrak; dan

3) Keadaan force majeure jika sifatnya sementara, hanyalah menunda kewajiban debitur, tidak mengakhiri kontrak kecuali ditegaskan dalam kontrak atau adanya kesepakatan parapihak.

Apabila mengikuti ketentuan tersebut, maka klaim force majeure diajukan dengan iktikad baik dan sesuai tata cara pemberitahuan yang disepakati dalam kontrak. Para pihak dalam suatu perikatan perlu memahami bahwa asas iktikad baik tidak hanya berlaku pada saat pelaksanaan kontrak, namun sejak persiapan kontrak (pre-contract), pelaksanaan kontrak (during the period of contract), dan penyelesaian sengketa (disputes settlement). ${ }^{9}$ Meskipun secara faktual terdampak pandemi COVID-19, pihak yang mengklaim force majeure harus dengan iktikad baik berusaha melakukan hal-hal yang dianggap patut dan wajar untuk tetap melaksanakan kewajiban atau paling tidak melakukan upaya utuk memitigasi risiko tidak terpenuhinya kewajiban berdasarkan kontrak. Kemudian terkait tata cara pemberitahuan, umumnya ditentukan bahwa pihak yang

Handri Rahardjo, 2009, Hukum Kontrak Di Indonesia, Pustaka Yustisia, Yogjakarta, h. 104

Agri Chairunisa Isradjuningtias, Force majeure (Overmacht) Dalam Hukum Kontrak (Kontrak) Indonesia, Jurnal Veritas Et Justitia, Volume 1, Nomor 1, 2015.

9 Nisrina Mutiara Dewi, Tinjauan tentang Keadaan Memaksa (Force majeure) dalam Sengketa Kontrak Murabahah di BNI Syariah Cabang Medan, Misykat al-Anwar Jurnal Kajian Islam dan Masyarakat, Volume 3, Nomor 1,2020, 
Kosmik Hukum Vol. 21 No. 1 (2021): 1-9

E-ISSN: 2655-9242 | P-ISSN: 1411-9781

DOI: 10.30595/kosmikhukum.v21i1.9407

mengalami/terdampak force majeure harus memberitahukan secara tertulis kepada pihak lain dalam kurun waktu tertentu sejak dampak tersebut dirasakan. ${ }^{10}$

Pengajuan klaim force majeure harus didasarkan pada rujukan hukum yang tepat. Pihak yang mengajukan klaim harus terlebih dahulu meneliti apakah bencana, pandemi atau tindakan pemerintah pemberlakuan aturan tertentu termasuk ruang lingkup force majeure yang diakomodasi dalam kontrak. ${ }^{11}$ Apabila, klaim force majeure didasarkan pada adanya tindakan pemerintah, pihak yang mengklaim dianjurkan untuk membuktikan bahwa adanya tindakan pemerintah tersebut secara nyata berdampak pada kegiatan/aktivitas bisnisnya. Dalam hal ini, apabila mengacu pada Pasal 1245 KUHPerdata, maka klaim diajukan dengan maksud untuk merubah kontrak dan bukan mengakhiri kontrak. Hal yang untuk dipahami adalah bahwa klaim adanya force majeure tidak serta merta menggugurkan kewajiban pihak tersebut. Ketentuan Pasal 1245 KUHPerdata bahkan hanya berkaitan dengan pembebasan atas kewajiban untuk mengganti rugi. Oleh karena itu, pada saat pengajuan klaim force majeure, pihak tersebut seharusnya telah menyiapkan alternatif perubahan kontrak terlebih dahulu. Sebagai contoh, misalnya berupa perubahan tenggat waktu pembayaran kredit/pembiayaan, penyesuaian kuantitas, kualitas barang/layanan, milestone kontrak maupun jadwal pelaksanaan layanan (delivery time). Apabila disepakati, maka perubahan kontrak tersebut lebih baik dituangkan dalam akta notariil dan menjadi bagian yang tak terpisahkan dari kontrak awal.

Selanjutnya, apabila mengutamakan penyelesaian secara musyawarah serta tetap tunduk pada tata cara penyelesaian sengketa, maka hal tersebut harus pula diatur dalam kontrak. Dalam melakukan negosiasi perubahan kontrak, para pihak harus sedapat mungkin mengutamakan penyelesaian secara musyawarah dan menghindari penyelesaian melalui litigasi. Dalam situasi saat ini, penyelesaian sengketa melalui jalur litigasi tidak hanya memerlukan proses yang panjang tetapi juga kompleks. Dapat dibayangkan, berapa banyak potensi perkara wanprestasi akibat pandemi COVID-19 yang akan diselesaikan di pengadilan terlebih ditengah situasi pembatasan jarak/fisik saat ini.

\section{Penutup}

Penetapan Pandemi Covid-19 sebagai Bencana Non Alam Penyebaran Covid-19 oleh Pemerintah memberikan dampak kepada para pihak dalam melaksanakan kewajiban dan mendapatkan haknya. Kondisi ini tentu merugikan beberapa sektor dan berdampak pada pelaksanaan kontrak. Kontrak mengikat dan memberikan kepastian hukum kepada para pihak sesuai dengan kesepakatan para pihak dengan dilandasi dengan itikad baik, dan tidak ada cacat hukum di dalamnya. Salah satu klausul yang dirujuk berkaitan dengan tertundanya atau hapusnya atau berakhirnya pelaksanaan kontrak adalah klausul Force majeure. Penerapan Klausul Force Majeure sebagai salah satu alasan bagi debitur yang gagal memenuhi prestasinya, perlu memperhatikan beberapa persyaratan dari karakter klausul Force majeure, yaitu sebagai berikut:

1) Jika dalam Kontrak para pihak telah menyatakan secara tegas bahwa wabah penyakit atau penutupan akses (lockdown) sebagai peristiwa force majeure, maka wabah virus corona dan lockdown oleh pemerintah dapat dijadikan sebagai alasan force majeure.

2) Perlu diperhatikan berkaitan dengan jenis prestasi yang akan dilaksanakan oleh para pihak, apabila pemenuhan prestasi masih di mungkinkan terpenuhi hanya mengalami kendala tertunda, maka tidak serta merta menggugurkan kewajiban dari para pihak dengan alasan force majeure. Hal ini dipahami bahwa kondisi pandemi covid ini merupakan keadaan yang bersifat sementara.

\footnotetext{
${ }^{10}$ Laras Sutrawaty, Force majeure Sebagai Alasan Tidak Dilaksanakan Suatu Kontrak Ditinjau Dari Perspektif Hukum Perdata, Jurnal Legal Opinion, Vol 4, No 3 (2016).

${ }^{11}$ Putra PM Siregar, Ajeng Hanifa Zahra, Bencana Nasional Penyebaran COVID-19 sebagai Alasan Force majeure, Apakah Bisa? https://www.djkn.kemenkeu.go.id/artikel/baca/13037/Bencana-Nasional-Penyebaran-COVID-19-sebagaiAlasan-Force-Majeure-Apakah-Bisa.html
} 
3) Kontrak sudah dibuat, dan berjalan pada saat munculnya pandemic covid, maka perlu diadakan renegosiasi oleh para pihak untuk mencari solusi

4) Waktu terjangkitnya pandemi Covid-19 dapat diprediksikan, atau tidak. Apabila kondisi pandemi covid 19 ini dipandang sebagai kondisi yang bersifat sementara, bukan permanen, maka masih memungkinkan untuk diadakan renegosiasi oleh para pihak yang terikat pada kontrak.

Berdasarkan persyaratan di atas, maka Penetapan Pemerintah bahwa Covid 19 sebagai Bencana Non Alam Medis, tidak dapat dikategorikan sebagai kondisi force majeure. Kontrak akan tetap berjalan sebagaimana semestinya dan tidak serta merta diputus dengan alasan terjadi force majeure. Bagi pihak yang mengalami kendala dalam pemenuhan prestasi, wajib membuktikan adanya hubungan sebab akibat yang nyata antara terjadinya pandemi covid 19 dengan ketidakmampuannya dalam menjalankan kewajiban sebagaimana tercantum dalam kontrak.

\section{Daftar Pustaka}

Erawati, Elly, \& Budiono, Herlien, Penjelasan Hukum Tentang Kebatalan Kontrak, Nasional Legal Reform Program-Gramedia, Jakarta, 2010,

Garner, Bryan A., ed, "Black's Law Dictionary, Tenth Edition," West Publishing Company, USA, 2014.

Hardjowahono, Bayu Seto (Chair), "Academic Text of the Draft Law on Contract Law, the National Legal Development Agency of Ministry of Law and Human Rights," Republic of Indonesia, p. 3. 2013.

Herlien Budiono, Elly Erawati, “Legal Explanation of Contract Cancellation, National Legal Reform Program" Gramedia, Jakarta, p. 5. 2010.

Isradjuningtias, Agri Chairunisa, "Force majeure (Overmacht) Dalam Hukum Kontrak (Kontrak) Indonesia", Jurnal Veritas Et Justitia, Volume 1, Nomor 1, 2015.

Marzuki, Peter Mahmud, "Penelitian Hukum", Kencana Prenada Media Group, Jakarta, (hereinafter referred to as Peter Mahmud Marzuki I), p. 35. 2011.

Mutiara Dewi, Nisrina, "Tinjauan tentang Keadaan Memaksa (Force majeure) dalam Sengketa Kontrak Murabahah di BNI Syariah Cabang Medan", Misykat al-Anwar Jurnal Kajian Islam dan Masyarakat, Volume 3, Nomor 1, 2020,

Dewi, Nisrina Mutiara, Tinjauan tentang Keadaan Memaksa (Force majeure) dalam Sengketa Kontrak Murabahah di BNI Syariah Cabang Medan, Misykat al-Anwar Jurnal Kajian Islam dan Masyarakat, Volume 3, Nomor 1, 2020,

Peeri, N. C, et. al."The SARS, MERS and novel coronavirus (COVID-19)epidemics, the newest and biggest global health threats: what lessons have we learned?". International Journal of Epidemiology, .p 1-10. 2020.

Rahardjo, Handri, 2009, Hukum Kontrak Di Indonesia, Pustaka Yustisia, Yogjakarta, p. 104

Sutrawaty, "Laras, Force majeure Sebagai Alasan Tidak Dilaksanakan Suatu Kontrak Ditinjau Dari Perspektif Hukum Perdata", Jurnal Legal Opinion Vol 4, No 3 (2016).

Putra PM Siregar, Ajeng Hanifa Zahra, Bencana Nasional Penyebaran COVID-19 sebagai Alasan Force majeure, Apakah Bisa? https://www.djkn.kemenkeu.go.id/artikel/baca/13037/Bencana-Nasional-PenyebaranCOVID-19-sebagai-Alasan-Force-Majeure-Apakah-Bisa.html 